\title{
1921 Maarif Kongresi'nin Türk Eğitim Tarihindeki Yeri Ve Önemi
}

Erol KAPLUHAN*

\section{ÖZET}

1921 y1lında Ankara'da toplanan Maarif Kongresi'nin eğitim tarihimiz içinde önemli bir yeri vardır. Bu kongre okul ve öğrenci mevcudunu tespit etmek, bu konuda yapılması gereken çalışmaları belirlemek ve eğitime millî bir yön vermek amacıyla toplanmıştır. Eğitim tarihimizde bir dönemin başlangıcı olarak görülmesi gereken bu kongrede Atatürk, eğitim, bilim ve kültür alanındaki düşüncelerini, yapılacak inkılâpların esaslarını, öğretmenler için neler düşündüğünü ve onlardan neler beklediğini anlatan tarihî bir konuşma yapmıştır. Yeni kurulan devletin çağdaşlaşma yolunda ilerlemesi için atılan adımların, yapılan inkılâpların halk tarafından benimsenmesinde, eğitim alanındaki yenilikler büyük rol oynamıştır. Türk Milleti için Kurtuluş Savaşının önemi ne kadar büyükse, bu savaşın en bunalımlı günlerinde toplanan Maarif Kongresinin de Türk eğitim tarihi açısından önemi büyüktür ve milli eğitim ve kültür politikalarının mihenk taşını oluşturmaktadır.

Anahtar Kelimeler: Maarif Kongresi, Eğitim, Türk Eğitim Tarihi

\section{The Role And Importance Of The 1921 Education Congress In Turkish \\ Educational History}

\section{ABSTRACT}

Congress held in Ankara in 1921, the Ministry of Education has an important place in the history of education This congress entity to identify schools and students, the work to be undertaken in order to determine the direction and education were collected from a national. Education should be seen as the beginning of a period of history that Congress Ataturk, education, science and culture in the thoughts and principles of revolutions do for teachers what they are thinking and what he expects from them, made a speech about the historical. The greater the importance of the Turkish War of Independence for the Nation, the most depressing days of the war, gathered at the Congress of Education History of Education in Turkey is of great importance and constitutes a cornerstone of the national education and cultural policies.

Keywords: Education Congress, Education, History of Turkish Education

* Yrd. Doç. Dr, Ahi Evran Üniversitesi Fen-Edebiyat Fakültesi Coğrafya Bölümü, EKapluhan@hotmail.com 


\section{Giriş}

I. Dünya Savaşında Çanakkale ve başka cephelerde büyük zaferler kazandığı halde, 30 Ekim 1918 Mondros Mütarekesi ile Osmanlı Devleti yenik sayılmış ve başkent İstanbul ile topraklarından birçok yeri işgal edilmeye başlanılmıştı.

Kurtuluş Savaşı Dönemi'nde (1919-1922) yürütülen bağımsızlık mücadelesi, eğitimi de derinden etkilemiştir. Bununla beraber, eğitim bu mücadeleye önemli katkılarda bulunmuştur. TBMM'nin açılışından hemen sonra, 6 Mayıs 1920 'de Maarif Vekilliği adıyla yeni bir teşkilât kurularak eğitimin millî bir sisteme göre ele alınması kabul edilmiştir. 25 Kasım 1920'de mecliste alınan bir kararla öğretmen ve öğrencilerin askerlik yükümlülükleri ertelenmiş, 15 Temmuz 1921'de savaşın en yoğun olduğu bir dönemde Ankara'da Maarif Kongresi toplanmıştır (Akyüz, 2009: 289-293).

Atatürk, toplumun yeniden biçimlendirilmesinde en önemli itici kuvvet olarak görülen eğitim alanında da aynı ilkeye uyulmasını, ilim ve fennin gösterdiği yoldan şaşılmamasını özellikle istemiş, hatta emretmiştir. Bu tutumuyla Atatürk, Türkiye'nin çağdaş bir devlet hâline gelmesini önleyen engelleri, tam bir cesaretle yıkıp atabilen, akıl ve bilim çağına geçmenin tek kurtuluş yolu olduğunu tam bir berraklıkla görüp bu gerçeği tam bir açıklıkla gözler önüne seren bir liderdir (Karagözoğlu, 1985: 204).

Atatürk için tükenmez inanç kaynağı, yüreğini kaplayan derin millet sevgisi ile Türk gençliğine duyduğu sonsuz güvendir. O, Türk Milleti'nin ve Türk gençliğinin başaracağına dair inancını kaybetmemiştir. Atatürk'ün Türk gençliği ile ilgili görüşlerini açıklayan en eski belge, 1918 yılı Mayıs ayında, bir fotoğrafin üzerine kendi el yazısıyla yazdıklarıdır. Burada Atatürk, gençliğe olan inancını ve duygularını şu sözlerle ifade etmiştir: "Her şeye rağmen muhakkak bir nura doğru yürümekteyiz. Bende bu imam yaşatan kuvvet, yalnız aziz memleket ve milletim hakkındaki payansız muhabbetim değil; bu günün karanlıklarl, ahlâksızlıkları, şarlatanlıkları içinde sırf vatan ve hakikat aşkıyla ziya serpmeye ve aramă̆a çalışan bir gençlik gördüğümdendir" (Demiroğlu, 1986: 603; Kocatürk, 1984: 162; Tikin, 1986: 94).

Atatürk'e göre millî eğitim, bağımsızlık savaşı kadar önemlidir. $O$, bunu Yunanlıların Kütahya-Eskişehir üzerinden Ankara'ya doğru saldırıya geçtikleri günlerde ispat etmiştir. Düşman bütün gücüyle saldırıya geçtiği sırada, 16-21 Temmuz 1921 tarihleri arasında, Ankara'da, millî eğitim-öğretim seferberliğini de başlatmıştır. Bu hareketiyle hem eğitim-öğretime verdiği önemi göstermiş, hem de iç ve dış kamuoyuna Türk ordusunun başarıya ulaşacağına 
emin olduğu imajını vermiştir. Bu dünya tarihinde hiç bir ülkenin yapmadığı, hiç bir devlet adamının düşünmeye cesaret edemediği bir harekettir

\section{1- 1921 Maarif Kongresi}

İlk TBMM döneminde Maarif Vekâleti görevine sırasıyla Rıza Nur, Hamdullah Suphi, Mehmet Vehbi ve İsmail Sefa Bey'ler getirilmiştir. Her biri eğitim ve öğretimin yeniden teşkilatlandırılması, müfredatların yeniden oluşturulması ve özellikle de öğretmen yetiştirilmesi meselelerinde önemli gayretler göstermiş ve o günün şartlarında tüm imkânları seferber etmişlerdir.

Milli eğitim politikasının temel amaçları belirlendiğinde ilk planlı faaliyet olarak mevcut okulların açık tutulması ve iyi idare edilmesi hedeflenmiştir. Mustafa Kemal'in yeni oluşumda öğretmenlerin rolü ve önemini en baştan beri önemseyerek savaş esnasında bir "Maarif Kongresi" tertiplenmesini istemesi de öğretmenlerin o günkü toplumsal konumu ve değerini göstermesi açısından dikkat çekicidir. Öğretmenlerin en az cephe gerisindeki milli ruhu ve manevi enerjiyi yüksek tutması kadar, eğitim öğretimin kendini yenileyebilmesi ve yeni bir hukuki çerçeve içerisinde devamlılı̆̆ının sağlanması için atılması gerekli adımları belirlemesi bakımından da "Birinci Maarif Kongresi" oldukça anlamlidir.

TBMM'nin açılışını müteakip eğitimle ilgili ilk sistemli hareket olarak tanımlanabilecek Maarif Kongresi, Kütahya- Eskişehir Savaşları'ndaki mağlubiyetin ardından Sakarya Savaşı'na hazırlık döneminde yapılmıştır.

Hâkimiyet-i Milliye, 31 Mayıs 1921 ve 13 Temmuz 1921 tarihli haberlerinde Maarif kongresi ifadesini kullanmaktadır. Ertesi günkü haberde de Maarif Kongresi'nin 15 Temmuz'da açılacağı bildirilmektedir (Sarıhan, 2009: 54).

Genellikle ilk ve ortaöğretim kademelerinin hedefi ve programı hakkında tartışmaların yapıldığı bu kongrede Atatürk, eğitim için harcanan çabaların gelecekteki eğitimin temellerini atmaya yetmeyeceğini; gerekli vasıtalara sahip olununcaya kadar geçecek olan devrede itina ile çizilmiş bir eğitim programı uygulanıp eğitim örgütünün en verimli şekilde çalıştırılacağını belirtmiş; kongrenin ilerleyen günlerinde ise öğretimin sadeleştirilmesi, uygulamalı hale getirilmesi ve yörelere göre çeşitlendirilmesi istenmiştir.

Maarif Kongresi, yurdun her tarafından gelen 250'den fazla erkek ve kadın öğretmeni bir araya getirmiştir. Kongreyi Mustafa Kemal cepheden gelerek açmış ve çok önemli bir açılış konuşması yapmıştır. Kongrenin açılışına uzun bir başyazı ayıran Hâkimiyet-i Milliye gazetesi, daha önceki iki İnönü savaşı ve başlamak üzere olan Sakarya savaşını kastederek, "Mustafa Kemal Paşa, 
126 • YALOVA SOSYAL BİLIMLER DERGİSİ

Üçüncü Yunan taarruzunun en ateşli zamanında muallim ordusunun gelecek vazifesiyle meşgul bulunuyor. Bu asil ve yüce örnek Türk tarihinin benzeri ender bulunan kıymetli hatıralarından biri olacaktır" demiştir (Akyüz, 2009: 320-321).

Atatürk kongreyi son derece önemli tespitler yaptığı açılış konuşmasıyla, bizzat kendisi başlatarak kongreye verdiği önemi bir kez daha ortaya koymuş ve konuşmasında:

"Muhterem Hanımlar; Efendiler!

Asırların mahmul olduğu derin bir ihmali idarinin bünye-i devlette vücuda getirdiği yaraları tedaviye masruf olacak himmetlerin en büyügü̈nü hiç şüphesiz irfan yolunda ibzal etmemiz lazımdır. (Yüzyılların yüklediği derin bir idare ihmalinin devlet varlığında açtığı yaraları gidermeyi sağlayacak çabaların en büyügünü, eğitim yolunda harcamamız gerekmektedir.)

...Irfanı memleket için tahsis edilebilen şey müstakbel maarifimize mabihilistinad olacak bir temel kurmağa kâfi değildir. Ancak vasi ve kafi şerait ve vesaite malik oluncaya kadar geçecek eyyam-l cidalde dahi kemal-i dikkat ve itina ile işlenip çizilmiş bir milli terbiye programı vücuda getirmeğe ve mevcut maarif teşkilatımızı bugünden müsmir bir faaliyetle çalıştıracak esaslart ihzar etmeğe hasr-ı mesai eylemeliyiz. (Bugün için memleketin aydınlanması uğruna ayrılabilecek şey; eğitimimizin geleceğine dayanak olacak bir temel kurmaya yeterli değildir. Ancak elverişli ve yeterli koşullarla araçları elde edinceye kadar geçecek savaş günlerinde de tam bir özenle işlenip çizilmiş bir ulusal eğitim programı yapmaya ve eldeki eğitim ve öğretim kuruluşlarımızı bugünden verimli bir çabayla çalıştıracak esasları hazırlamaya bakmalıyız.)

Simdiye kadar takip olunan tahsil ve terbiye usullerinin milletimizin tarihi tedenniyatında en mühim bir amil olduğu kanaatindeyim. Onun için bir milli terbiye programindan bahsederken, eski devrin hurafatından ve evsafi fitriyemizle hiç de münasebeti olmayan yabancı fikirlerden, şarktan ve garptan gelebilen bilcümle tesirlerden tamamen uzak, seciye-i milliye ve tarihiyemizle mütenasip bir kültür kastediyorum. Çünkü dehayı milliyemizin inkişaf-ı tamı ancak böyle bir kültür ile temin olunabilir. Lalettayin bir ecnebi kültürü şimdiye kadar takip olunan yabancı kültürlerin muhrip neticelerini tekrar ettirebilir. Kültür zeminle mütenasiptir. O zemin milletin seciyesidir. (Şimdiye kadar sürüp gelen okuma ve yetiştirme yanlışl1klarının ulusumuzun gerilemesinde en önemli nedenlerden biri olduğu kanısındayım. Onun için bir ulusal yetiştirme programından söz açarken, eski çağdaki asılsız uydurmalardan, yaradılışımıza 
hiç de uymayan yabancı düşüncelerden, Doğu'dan ve Batı'dan aşırma bütün etkilerden büsbütün uzak, ulusal ve tarihsel doğamıza uygun bir kültürü öne sürmüş oluyorum. Çünkü Türk idaresinin gerçek gelişmesi ancak böyle bir kültürle sağlanabilecektir. Rastgele bir yabancı kültürü kabullenmek, şimdiye kadar uygulanıp duran yabancı kültürlerin yıkıcı sonuçlarını tekrar etmekten başka işe yaramaz. Kültürün, bu düşünce ekininin verimi, ekildiği yerin elverişliliği ile orantılıdır. Bu yer de milletin karakteridir.)

İste biz, bu kongrenizden yalnız, çizilmis eski yollarda alelade yürümenin tarzı hakkında müdavele-i efkâr etmeğe değil, belki serdettiğim şeraiti haiz yeni bir sanat ve marifet yolu bulup millete göstermek ve o yolda yeni nesli yürütmek için rehber olmak gibi mukaddes bir hizmet bekliyoruz... (İşte biz bu toplantınızdan yalnız, çizilmiş eski yollarda nasıl yürüyüp gidileceği hakkında beylik düşünceler ileri sürüp dağılmayı değil, belki de bu ortaya koyduğum koşullar çerçevesinde ulusa, yeni bir sanat ve bilim göstermek ve yeni kuşağı o yolda yürütmek için önder olmak gibi kutsal bir yararlılık bekliyoruz.)

İstikbal için hazırlanan evlad-ı vatana, hiçbir müşü̈l karşısında serfuru etmeyerek kemal-i sabır ve metanetle çalışmalarını ve tahsildeki çocuklarımızin ebeveynine de yavrularının ikmal-i tahsil için her fedakârliğı ihtiyardan çekinmelerini tavsiye ederim... Milletimizin saf seciyesi istidat ile malidir. Ancak bu tabi istidati inkişaf ettirebilecek usullerle mücehhez vatandaşlar lazımdır. Bu vazifede sizlere teveccüh ediyor. Hükümet-i Milliyemizin kemal-i ciddiyet ve samimiyetle arzu ettiği derecede, Türkiye muallime ve muallimlerinin hayat ve refahını henüz temin edememekte olduğunu bilirim. Fakat milletimizi yetiştirmek gibi mukaddes bir vazifeyi deruhte eden heyeti mübeccelenizin bugünün vaziyetini nazarl itibara alacağından ve her müşülü iktiham ile bu yolda gayet metinane yürüyeceğinden şüphem yoktur. Vazifeniz pek mühim ve hayatidir. Bunda muvaffak olmanız cenabı haktan temenni ederim". (Gelecek için hazırlanan yurt çocuklarına, hiçbir zorluk karşısında baş eğmeyerek sabırla, güvenle çalışmalarını ve yetişmekte olan çocukların büyüklerine de yavrularının okumalarını sağlamak için hiçbir fedakârlıktan çekinmemelerini salık veririm. Milletimizin yaratılıştan gelen elverişliliğini geliştirmek sizlere düşüyor. Türk öğretmenlerine ulusal hükümetimizce, candan ve gönülden istendiği kadar iyi ve rahat yaşama koşullarının sağlanamamış olduğunu bilirim. Ama ulusumuzu yetiştirmek gibi kutsal bir ödevi benimsemiş olan yüce topluluğunuzun bugünkü şartları göz önünde bulundurarak, her türlü güçlüğü göze alarak bu yolda sarsılmadan yürüyeceğine de güvenim vardır. Göreviniz pek önemlidir, ulusun yaşamasıyla yakından 
ilgilidir. Bunda başarılı olmanızı Tanrıdan dilerim.) (ASD, 2006: 19-21, Bugünkü Türkçesi Çağlar, 1968: 75-77)

Atatürk'ün de sözlerinden anlaşılacağı üzere yeni Türk Devleti'nin eğitim anlayışı, özgün bir kültür yaratma, pozitivist ve millî olma çizgisindedir. Yine aynı kongrede, bakanlık tarafından halk mektepleri hakkında düzenlenen bir projeyle, çocukları hayat içinde başarılı olacak bir kabiliyette yetiştirmek için yeni bir programın hazırlanmasının zorunluluğu tartışılır; dört sene olan ilköğrenimin beş seneye çıkarılması uygun görülerek, o zamana kadar uygulanan ilköğretim programlarının uygulanabilir olmadığı, altı senelik iptidai okullarında okutulan birçok derse ihtiyaç olmadığı, halk eğitimi için yüksek programların değil, halkın daha çok ihtiyaç duyduğu ve istediği lisan, din ve hesap gibi derslerin okutulmasiyla yetinilmesini, halk eğitiminin ancak bu şekilde sağlanabileceğini, köylü ve kentlilerin ihtiyaçlarının farklı olması sebebiyle ilkokul programlarının buna göre ayrı ayrı düzenlenmesi gerektiği; projede yer alan meslek derslerinin ilkokullarda bütünüyle öğretilmesinin mümkün olmadığı, ancak sanat ve bir is için kabiliyetlerin esas olduğu ve kız okullarına, kızların ev kadını olabilmeleri için gerekli pratik bilgilerin konulması gerektiği belirtilir (Millî Eğitim Şûraları, 1995:6).

Genellikle ilk ve ortaöğretim kademelerinin hedefi ve programı hakkında tartışmaların yapıldığ çabaların, gelecekteki eğitimin temellerini atmaya yetmeyeceğini; gerekli vasitalara sahip olununcaya kadar geçecek olan devrede itina ile çizilmiş bir eğitim programı uygulanıp, eğitim örgütünün en verimli şekilde çalıştırılacağını belirtiyordu.

Kongrenin daha sonraki günlerinde öğretimin sadeleştirilmesi uygulamalı hale getirilmesi ve yörelere göre çeşitlendirilmesi isteniyordu. Kongrede bir konuşma yapan Maarif Vekili Hamdullah Suphi Bey ise, bu doğrultuda şöyle konuşuyordu: "Maarif siyasetimiz, milletin kitle-i esasiyesini teşkil eden çiftçi ve iş̧i sinıfinin her şeyden evvel nazar-ı dikkat önünde tutulmasına ve yeni istikametin bu umdeye dayanmasına bağlıdır. Anadolu gene bir sanat merkezi olacaktır. Halkın geçimini yükseltecek ve islah edecek nazarî ve amelî bilgiyi vermek hedeftir" (Ergün, 1997: 8).

Özellikle kongreye kadın ve erkek öğretmenlerin karma olarak katılmaları, Mecliste Hamdullah Suphi Bey’e karşı sert eleştirilere neden olmuş, Bakan görevden çekilmiştir.

Hamdullah Suphi Bey hakkında verilen soru önergesinde Maarif Kongresi iki bakımdan eleştiri konusu olmuştur: Kongre için harcanan para ve kongreye kadın öğretmenlerin de katılmış olması. Bakan harcanan para konusunda 
açıklamalar yapmış, kongrenin karma olması konusunda da açıklama yapmaya hazırlanırken bundan vazgeçmiştir. Bay ve Bayan öğretmenlerin kongrede bir arada bulunmalarına tepki gösteren muhafazakâr mebuslara karşı Mustafa Kemal Paşa tepki göstermiştir (Sarıhan, 2009: 128-129).

Kongrenin gündemini "istatistikî bilgiler, nüfusun unsurlara göre taksimi, mekteplerin miktarı ve dereceleri, mektep binaları, muallimlerin adedi, muallimlerin dereceleri, talebenin adet ve dereceleri, öğrenci velilerinin işi, k1z okulları ve miktarı ile dereceleri, inas mekâtib-i tâliyesine (orta derece) karşı halktaki değerlendirme, Meşrutiyetten beri memleketin maarifinde tedenni veya inkişaf suretiyle vaki olan tahavvül, mekâtib-i hususiye ve ecnebiye, ziraat ve sanayi mekteplerinin hâli, sıbyan mektepleri, evkâf-1 münderise (izi kalmamış vakıflar), maarifçe bunlardan edilecek istifade, mahalli maarifin inkişafi için düşünülen hususât, iktisadi malûmât, mahalli istihsalât hakkında malûmat, bu istihsalâtı mekteplerimize tanıtmak için yerli mütehassısların olup olmadığı, medenî, ziraî, sanaî nokta-i nazardan meselenin tetkiki ve hangileri inhitat etmek üzere olduğu, masarıf-1 mecburenin mekteplerden gayri ne gibi yerlerde kullanıldığı, son beş sene zarfında bu kısım varidâtın mekteplere geçen kısmı, hisse-i maarifin mahallîne sarf edilip edilmediği" konuları oluşturmuştur.

Maarif Kongresi'nin ikinci toplantısı Dârülmuallimîn binasındaki konferans salonunda Maarif Vekili Hamdullah Suphi Bey’in Başkanlığında yapılmıştır. Bakanlık tarafından halk mektepleri hakkında düzenlenen bir proje tartışılmıştır. Bu projede, çocukları hayat içinde başarılı olacak bir kabiliyette yetiştirmek için bir programın hazırlanmasına ihtiyaç olduğu belirtilmiş ve dört sene olan ilköğrenimin beş seneye çıkarılması uygun görülmüştür. Projede yer alan meslek derslerinin ilkokullarda bütünüyle öğretilmesinin mümkün olmadığı, ancak sanat ve bir iş için kabiliyetlerin esas olduğu ve kız okullarının, kızların ev kadını olabilmeleri için gerekli pratik bilgilerin konulması gerektiği belirtilmiştir.

Maarif Kongresi 3. toplantısında "Ortaöğretim" konusu ele alınmış ve orta dereceli okul programlarını ve özellikle idadî teşkilatı tartışılmıştır. Kongrenin son toplantısında ilk ve ortaöğretimin hedefi ve programı hakkında yapılan tartışmalar sonucunda tam bir görüş birliği sağlanmış, kongreye katılanların tümü eğitimi sadeleştirmek, uygulanabilir hâle getirmek ve mahallîleştirmek gerektiği üzerinde fikir birliğine varmıştır.

Maarif Kongresi, önceden kararlaştırıldığı kadar bir süre çalışamadığı gibi, gündemindeki konuların hepsini inceleyememiş, incelenen konular da yeterli bir derinlikte ele alınamamıştır. Bunun nedeni, savaşın bütün şiddetiyle de- 
vam etmekte olmasıdır. Ancak bu şartlara rağmen, ilk ve ortaöğretime ilişkin bazı önemli konular tartışılmıştır.

Maarif Kongresinde her ne kadar önemli bir karar alınamamışsa da dönemin ağır savaş koşulları altında Türkiye'nin önemli eğitim sorunlarına bu kadar geniş bir katılımcı kitlesiyle tartışılması çok önemli bir olaydır.

Kongrede Sivas Maarif Müdürü Osman Nuri Bey'in Mustafa Kemal'e delegeler adına verdiği cevap ve İstanbul'daki Muallimler Cemiyeti genel kurulunun kongreye gönderdiği mesaj, o dönemin öğretmen anlayışını göstermesi açısından önemlidir. Gerek Anadolu'daki, gerek İstanbul'daki öğretmenler, bağımsızlığın ve çağdaşlaşmanın öncüsü olmaları gerektiğinin bilincindedirler. Bu konuda, hükümetle ve eğitim bakanlığ 1 ile görüştedirler. Yurtsever bir gençlik yetiştirmeye ve savaşın getirdiği yokluklara karşı dayanmaya hazırlıklıdırlar. Öğretmenlerin birliği için çalışmaktadırlar.

\section{2- Maarif Kongresine Katılanlar}

15 Temmuz 1921 tarihinde "Muallim ve Muallimeler Cemiyetleri Birliği" tarafindan toplanan kongreye Maarif Müdürleri, Sultani, Darulmuallimin gibi Lise Müdürleri ve Maarif Müfettişleri katılmıştır. İsmail Hakkı Tonguç, 1946'da yayımlanan İlköğretim Kavramı adlı kitabında kongreye çağrılanları şöyle sınıflandırmaktadır: Elyevm bilfiil ögretmen olanlar, Maarif Müdürleri (İşgal altında olmayan 40 civarında maarif müdürü), Mektep Müdürleri, Telif ve Tercüme azaları, Maarif Vekâleti daire azaları, Âli dersler ve konferanslar müderrisleri, Her gazete adına bir mümessil olmak üzere gazete müderrisleri (Tonguç, 1946:213).

Yenigün gazetesi kongrenin toplanacağ gün verdiği haberde Maarif Kongresine dahil olabilecekleri şöyle sıralamaktadır:

"Halen muallim olanlar, (muallim ve muallimeler) maarif müdürleri, mektep müdür ve müdireleri, Telif ve Tercüme Heyeti üyeleri, Maarif Vekâleti Müfettişleri, Ali Dersler ve konferanslar müderris ve müderrisanları, gazete mümessilleri (her gazete namına bir mümessil) kongreye iştirak edecektir. Ankara Maarif Müdüriyeti'nden bir giriş belgesi alacaklar ve defteri mahsusuna imzalarını kaydettireceklerdir" (Yenigün: 14 Temmuz 1921:1).

Kongreye katılanlarla ilgili kesin sayı belirli değildir. Ayrıca listesi de elde yoktur. Yahya Akyüz, Hakimiyet-i Milliyenin 1921 tarihli haberini kaynak göstererek kongreye 250 'den fazla erkek ve kadın öğretmen, okul müdürü ve maarif müdürünün katıldığını yazmaktadır.

Kongreye katılanlar arasında bayanlarında olduğu bilinmektedir, ancak sayıları hakkında kesin bir bilgi yoktur. Haberlerde adı geçen üç kadın vardır: 
Yüksek dersler öğretmenlerinden Halide Edip Adıvar'la, Müfide Ferit Tek ve Kız Öğretmen Okulu Müdiresi Şahur Hanım (Sarıhan, 2009: 66).

Tablo 1: Maarif Kongresine Katılanlar

\begin{tabular}{|c|c|}
\hline \multicolumn{2}{|l|}{ Üst Düzey Yöneticiler } \\
\hline \multicolumn{2}{|c|}{ 1- Mustafa Kemal Paşa (TBMM Başkanı) } \\
\hline \multicolumn{2}{|c|}{ 2-Adnan Adıvar (TBMM İkinci Başkanı) } \\
\hline \multicolumn{2}{|c|}{ 3- Hamdullah Suphi Tanrı̈̈ver (Eğitim Bakanı) } \\
\hline \multicolumn{2}{|c|}{ 4- Kazım Nami Duru (Orta Öğretim Genel Müdürü) } \\
\hline \multicolumn{2}{|c|}{ 5- Ahmet Edip Bey (İlköğretim Genel Müdürü) } \\
\hline \multicolumn{2}{|c|}{ 6- Vasıf Bey (Eğitim Bakanlığı Özel Kalem Müdürü) } \\
\hline \multicolumn{2}{|c|}{ Yüksek Dersler Müderrisleri } \\
\hline 7- Ziya Gökalp & 18- Riza Nur Bey \\
\hline 8- Nafi Atuf Bey & 19- Akçora Yusuf Bey \\
\hline 9- Yakup Kadri & 20- Mithat Bey \\
\hline 10- Ruşen Eşref Bey & 21- Niyazi Bey \\
\hline 11- Veled Çelebi Efendi & 22- Veli Bey \\
\hline 12- A ğaoğlu Ahmet Bey & 23- Mahmut Esat Bey \\
\hline 13- Halide Edip Hanım & 24- Mustafa Şeref Bey \\
\hline 14- MüfideFerit Hanım & 25- Suat Bey \\
\hline 15- Adnan Bey & 26- Hüseyin Bey \\
\hline 16- Ali Suat Bey & 27- Mehmet Vehbi Bey \\
\hline 17- Fuat Bey & 28- Cemal Hüsnü Bey \\
\hline \multicolumn{2}{|l|}{ Üniversite } \\
\hline \multicolumn{2}{|l|}{ 29- İsmail Hakk1 (Baltacıoğlu) } \\
\hline \multicolumn{2}{|l|}{ 30- Mehmet Emin (Erişirgil) } \\
\hline \multicolumn{2}{|l|}{ Ĕgitim Müdürleri } \\
\hline 18- Haydar Bey (Isparta) & 39- Osman Nuri Bey (Sivas) \\
\hline 19- Avni Bey (Yozgat) & 40- Hakkı Hilmi Bey (Konya) \\
\hline 20- Refet Bey (Adana) & 41- İhsan Hami Bey(Diyarbakır) \\
\hline 21- Talat Bey (Bolu) & 42- Sadık Bey (Samsun) \\
\hline 22- Zakir Bey (Afyonkarahisar) & 43- Adil Bey (Kastamonu) \\
\hline 23- Haydar Bey (Burdur) & 44- Ahmet Nuri Bey (Aydın) \\
\hline 24- Cudi Bey (Siirt) & 45- Şükrü Bey (Ankara) \\
\hline
\end{tabular}




\begin{tabular}{|ll|}
\hline 25- & Baha Tevfik Bey \\
\hline Okul Müdürleri \\
\hline 47- & Eşref Bey (Konya Öğretmen Okulu Müdürü) \\
\hline 48- & Osman Nuri Bey (Konya Sultani Müdürü) \\
\hline 49- & Avni Bey (Konya'da Tatbikat Öğretmeni) \\
\hline $50-\quad$ Mehmet Fuat Gündüzalp (Bartın Lisesi Müdürü) \\
\hline $51-\quad$ Şahur Hanım ( Ankara Kı̈ Öğretmen Okulu Müdiresi) \\
\hline
\end{tabular}

Kaynak: Sarıhan, 2009: 148-149.

\section{Sonuç}

1921 Maarif Kongresi, yeni bir kültürel eğitim hamlesi olarak Türk eğitim tarihine kaydedilmiştir. Türk eğitim tarihinde çok önemli yere sahip olan 1921 Maarif Kongresi, 20 yüzyıl başlarında ortaya çıkan milliyetçilik akımının yarattığı birikimle kültür ve eğitimde Batı'ya ve ortaçağ değerlerine direnişi sembolize etmektedir.

15 Temmuz 1921'de toplanan Maarif Kongresi, TBMM Hükümeti'nin ikinci eğitim bakanı olan Hamdullah Suphi'nin eseridir. Hamdullah Suphi kongrede, kendisinin daha önce çeşitli vesilelerle dile getirdiği görüşleri ve bakanlığının tasarılarını kabul ettirmiştir.

Kongreye Anadolu'nun değişik yerlerinden ancak çoğunluğu Ankara'dan olmak üzere 180 'le 250 arasında kişi katılmış ve kongreyi Atatürk, ulusal eğitimin temellerini açıklayan konuşması ile açmış, bu konuşma ve mevcut koşullarda bir eğitim kongresi toplanması, o günün basınında övgüyle ve takdirle karşılanmıştır. İki hafta sürmesi planlanan kongre, Yunanlıların Anadolu içlerine doğru ilerlemesi üzerine çalışmalarını yarıda keserek dağılmıştır.

1921 Maarif Kongresi, diğer eğitim kurultayları gibi danışma mahiyetindedir. İlk ve orta öğretimin hem içeriğini, hem öğretim sürelerini tartışmış, ancak varılan sonuçları uygulayamamıştır.

Atatürk'e göre millî eğitim, bağımsızlık savaşı kadar önemlidir. $O$, bunu Yunanlıların Kütahya-Eskişehir üzerinden Ankara'ya doğru saldırıya geçtikleri günlerde ispat etmiştir. Düşman bütün gücüyle saldırıya geçtiği sırada, 16-21 Temmuz 1921 tarihleri arasında, Ankara'da, millî eğitim-öğretim seferberliğini de başlatmıştır. Bu hareketiyle hem eğitim-öğretime verdiği önemi göstermiş, hem de iç ve dış kamuoyuna Türk Ordusu'nun başarıya ulaşacağına emin olduğu imajını vermiştir. Bu dünya tarihinde hiç bir ülkenin yapmadığı, hiç bir devlet adamının düşünmeye cesaret edemediği bir harekettir. 
Atatürk, hayatı boyunca eğitime ve eğitimcilere önem vermiş, her firsatta öğretmenleri ve öğretmenlik mesleğini yüceltmiştir. 1921 de toplanan Maarif Kongresi bunun en büyük ispatıdır bu yönüyle de Türk eğitim tarihi açısından çok büyük önem arz etmektedir.

1921 Maarif Kongresi, dünyanın yeni koşullarında, vatanı, ulusal birliği bir bütün olarak ulusal varlığı tehlike altında olan Türk Ulusu için, yeniden dirilişe güç verecek önemli bir olgudur. Türk Milleti için kurtuluş savaşının önemi ne kadar büyükse, bu savaşın en bunalımlı günlerinde toplanan Maarif Kongresi'nin de Türk eğitim tarihi açısından önemi büyüktür ve milli eğitim ve kültür politikalarının mihenk taşını oluşturmaktadır. 


\section{KAYNAKÇA}

Akyüz, Y. (2009). Türk Eğitim Tarihi (M.Ö. 1000-M.S. 2009), 14. Bask1, Pegem Akademi Yayınc1lık, Bask1 Cantekin Matbaası, Ankara.

Atatürk'ün Söylev ve Demeçleri (ASD), Cilt I-III (Açıklamalı Dizin İle) (2006), 5. Bask1, Türk İnkılâp Tarihi Enstitüsü Yayınları:1, Ankara.

Çağlar, B. K. (1967), Bugünkü Diliyle Atatürk'ün Söylevleri, A.Ü. Basımevi, Ankara.

Demiroğlu, C. (Temmuz 1986), “Atatürk ve Gençlik”, Atatürk Araştırma Merkezi Dergisi, C. II, Say1: 6, s. 603, Ankara.

Ergün, M. (1997), Atatürk Devri Türk Eğitimi, (I.Bask1 Ankara Dil Tarih Coğrafya Fakültesi Yayınları No:325, Ankara 1982), 2. Bask1, Ankara: Ocak Yayınları.

Hakimiyet-i Milliye Gazetesi:21 Temmuz 1921, Maarif Kongresi, Pek Veciz Bir Nutuk.

Karagözoğlu, G. (1985), “Atatürk’ün Eğitim Savası”, Atatürk Araştırma Merkezi Dergisi, Cilt:2, Sayı:4, s. 193-213, Ankara.

Kocatürk, U. (1984), Atatürk'ün Fikir ve Düşünceleri, III. Basım, s. 162, Ankara.

Milli Eğitim Şuraları (1939-1993) , (1995), T. C. Millî Eğitim Bakanlığı Talim ve Terbiye Kurulu Başkanlığı Şûra Genel Sekreterliğii. Millî Eğitim Basımevi, Ankara.

Sarıhan Z. (2009), 1921 Maarif Kongresi, Milli Eğitim Bakanlığı Yayınları:4715, Bilim ve Kültür Eserleri: 1493, Ankara.

Tikin, A. (1986), “Atatürk ve Gençlik”, İ.Ü. Atatürk İlkeleri ve İnkılâp Tarihi Yıllı̆̆ı I, s. 94. İstanbul.

Tonguç, İ. H. (1946), İlköğretim Kavramı, Remzi Kitabevi, İstanbul.

Yenigün, (14 Temmuz 1921), "Maarif Kongresi”, Sayı: 657-279, s.1, sü. 6. 